\title{
USING MATLAB TO HELP STUDENTS UNDERSTAND GAUSS-JORDAN METHODS
}

\author{
Rindu Alriavindra Funny \\ Teknik Penerbangan \\ Sekolah Tinggi Teknologi Adisujipto \\ J1. Janti Blok R Lanud Adisutjipto Yogyakarta \\ rindualri@stta.ac.id
}

\begin{abstract}
There are many variation of Gauss-Jordan Calculator. Students can use it to solve various types of linear equations. But all of them just straightly show the result. There is no such calculator which shows the step by step to get the result. Therefore, the students cannot understand how to do GaussJordan Elimination. One program that can be developed to make Gauss-Jordan calculator is matlab. This article examines matlab program which can help students to understand Gauss-Jordan Elimination methods. It tends to focus on the process to get solution. This program reveals with the step by step of operation in Gauss-Jordan to make reduced row-echelon form. Numbers of operations drawn in the solutions of linear simultaneous equations have also been showed. This paper has a propensity to appraise the performance of matlab program in solving linear equation problems with $n$ variables while showing every steps of Gauss-Jordan Elimination. Further it has the potential to develop this program to be a calculator that can be access without opening matlab.
\end{abstract}

Key Word: Matlab, Gauss-Jordan, Elimination, steps operation

\begin{abstract}
Abstrak
Calculator Gauss-Jordan adalah semacam program computer yang dapat menyelesaikan suatu permasalahan sistem persamaan linear dengan menggunakan Metode Eliminasi Gauss Jordan. Banyak sekali variasi calculator seperti itu di dunia maya. Saat ini siswa dapat dengan mudah menggunakan calculator tersebut untuk menyelesaikan sistem persamaan linear. Tetapi semua variasi calculator ini hanya langsung menunjukkan hasil akhirnya. Tidak ada calculator Gauss-Jordan yang menunjukkan langkah-langkah mendapatkan solusinya atau biasa dikenal dengan operasi baris elementer. Hal ini mengakibatkan siswa tidak dapat memahami bagaimana cara kerja metode GaussJordan. Salah satu program computer yang dapat digunakan untuk membuat Gauss-Jordan calculator adalah matlab. Penelitian ini akan menggunakan program computer matlab untuk membuat calculator Gauss-Jordan yang selain menyelesaikan sistem persamaan linear, juga dapat menunjukkan operasi baris elementer yang dilakukan sehingga mendapatkan baris eselon tereduksi. Calculator Gauss-Jordan pada penelitian ini masih harus dibuka dalam program matlab, sehingga kedepannya diharapkan program ini dapat digunakan tanpa harus membuka matlab.

Kata kunci : Matlab, Gauss-Jordan, Eliminasi, Langkah Operasi
\end{abstract}

\section{Introduction}

In science and engineering, system of linear equations arises in various theoretical research and applications. Gauss-Jordan Elimination is well known technique to determine a common solution in linear algebra. This method asked the Linear Equation System to be Matrices. Then is will solve by making the matrix into reduced row-echelon form. The way to change the matrix into the reduced row-echelon form is not easy. We have to try several operation possibilities. Although solving linear equation system using Gauss-Jordan Methods is not easy, but this method allowed us to solve equation system for $\mathrm{n}$ variables. Therefore, Gauss-Jordan method is very important to be learned.

In the school, when solving systems of equations by using matrices, many teachers present a Gauss-Jordan elimination approach to row reducing matrices that can involve painfully tedious operations with fractions (Smith and Powell, 2011) as well as in the 
Campus. In Sekolah Tinggi Teknologi Adisujipto (STTA) majoring Aeronautica Engineering, Linear Equation System is taught in Engineering Mathematic II of the second semester of 2016-2017 which related to Matrix. Based on the students' result in Final Test (2016-2017), many students did operations that do not lead to reduces row-echelon form and error while counting the operation to solve the Linear Equation system by Gauss-Jordan Method. They need tools to know what kind of operations need to get reduced row-echelon form and why it is so.

Gauss-Jordan calculator is one of the solutions to solve system of linear equation. Various type of this calculator will easily found in internet. But all of them just show the final result of common solution of linear equation systems. This calculator could be useful for application but not for learning. Students tend to use this calculator to solve linear equation systems. But when they asked to show how the steps to get the solution, they get confused. Therefore, for students in learning process Gauss-Jordan calculator is not really helpful.

This kind of calculator is developed by various computer languages programs. One of them is Matlab. Matlab (Matrix Laboratory) is a tool for numerical computation and visualization. The basic data element is a matrix, so this program could manipulates arraybased data fast and correct. For engineering students, matlab is also familiar.

This study will make a program using Matlab to solve linear equation system by GaussJordan Elimination. The program could show the steps to find the reduced row-echelon form in order to help students understand how to find the suitable operation. Next, the program will be showed to the students to get their opinion.

This program is very helpful for students to know what kind of operations should do to make the reduced row-echelon form. The students were very interested to this program. They thought it was awesome since this program is very dynamic. It can be used for any type of square matrix with any element of it. The most important things from this program is showing the steps of operation to get reduced row-echelon form.

\section{Background Theory}

\subsection{System of Linear Equation}

Systems of linear equations play an important and motivating role in the subject of linear algebra. In fact, many problems in linear algebra reduce to finding the solution of a system of linear equations.

Linear Equation is unknowns $x_{1}, x_{2}, \ldots, x_{n}$ is an equation that can be put in the standard form

$$
a_{1} x_{1}+a_{2} x_{2}+\cdots+a_{n} x_{n}=b
$$

where $a_{1}, a_{2}, \ldots, a_{n}$, and $\mathrm{b}$ are constants. The constant $a_{k}$ is called the coefficient of $x_{k}$, and $\mathrm{b}$ is called the constant term of the equation.

A solution of the linear equation (1.1) is a list of values for the unknowns or, equivalently, a vector $u$ in $K^{n}$,say

$$
x_{1}=k_{1}, \quad x_{2}=k_{2}, \quad \ldots, x_{n}=k_{n} \text { or } \quad u=\left(k_{1}, k_{2}, \ldots, k_{n}\right)
$$

such that the following statement (obtained by substituting $k_{i}$ for $x_{i}$ in the equation) is true:

$$
a_{1} k_{1}+a_{2} k_{2}+\cdots+a_{n} k_{n}=b
$$

in such a case we say that $u$ satisfies the equation.

A system of linear equations is a list of linear equations with the same unknowns. In particular, a system of $m$ linear equations $L_{1}, L_{2}, \ldots, L_{m}$ in $n$ unknowns $x_{1}, x_{2}, \ldots, x_{n}$ can be put in the standard form. 


$$
\begin{aligned}
& a_{11} x_{1}+a_{12} x_{2}+\cdots+a_{1 n} x_{n}=b_{1} \\
& a_{21} x_{1}+a_{22} x_{2}+\cdots+a_{2 n} x_{n}=b_{2} \\
& a_{m 1} x_{1}+a_{m 2} x_{2}+\cdots+a_{m n} x_{n}=b_{m}
\end{aligned}
$$

where the $a_{i j}$ and $b_{i}$ are constants. The number $a_{i j}$ is the coefficient of the unknown $x_{j}$ in the equation $L_{i}$.

The system (1.2) is called $m \times n$ (read: $m$ by $n$ ) system. It is called a square system if $m=n$, that is, if the number $m$ of equations is equal to the number $n$ of unknowns.

The system (1.2) is said to be homogenous if all the constant terms are zero, that is, if $b_{1}=0$, $b_{2}=0, \ldots, b_{m}=0$. Otherwise the system is said to be nonhomogeneous.

A solution (or a particular solution) of the system (1.2) is a list of values for the unknowns or, equivalently, a vector $u$ in $K^{n}$, which is a solution of each of the equations in the system. The set of all solutions of the system is called the solution set of the general solution of the system.

\subsection{Gauss-Jordan Elimination}

There are many ways to find the solution system of linear equation. Gauss-Jordan elimination is the common way used by students when the system of equations transformed into matrices (Smith and Powell, 2011). Gauss - Jordan method is a variation of the Gaussian elimination. In 1887, Wilhelm Jordan described while Gaussian elimination places zeros beneath each pivot in the matrix starting with the top row and working downwards, Gauss Jordan elimination method goes a step advance by placing zeroes above and below each pivot. It is named after Carl Friedrich Gauss and Wilhelm Jordan because it is a variation of Gaussian elimination.

Every matrix has a reduced row stratum form and Gauss - Jordan elimination is assured to find it. The method of solving a linear system by Gauss-Jordan elimination is called an algorithm. An algorithm can be defined as "a finite procedure, written in fixed symbolic vocabulary, governed by precise instructions.

Gauss-Jordan elimination is well suited for solving linear systems on a computer, at least in principle. In practice, however, some tricky problems associated with round off errors can occur. There are some analysts found that proliferation of round off errors can be reduced by modifying Gauss-Jordan elimination, developing more sophisticated reduction techniques. In modifying Gauss-Jordan elimination, we transform a matrix A into a matrix B by sequence of elementary row operations, which is in reduced row-echelon form.

The reduced row-echelon form can be thought of as trying to capture the idea of a triangular system where some equations are missing. It further restricts attention to particularly nice triangular forms that cannot be made to look nicer. A matrix is said to be in reduced row-echelon form if it satisfies the following conditions:

1) For every row, the left-most nonzero entry, if any, is a 1 . We will call this the pivotal entry for the row and the column where this appears the pivotal column. It is possible for a row to be all zeros.

2) The pivotal column for a later (lower) row is a later (more to the right) column, if it exists. If a given row is all zeros, all later rows are also all zeros.

3) Any column containing a pivotal 1 must have all other entries in it equal to 0 . This has two subparts:

a) All entries in the column below the pivotal 1 are equal to 0 (note that this is redundant if we assume both 1 and 2). 
b) All entries in the column above the pivotal 1 are equal to 0 . Of the above, 3(b), while part of the definition of reduced row-echelon form, is not necessary for the system to be triangular.

Converting a system into reduced row-echelon form, we must do elementary row operations.

1) Multiply or divide a row by a nonzero scalar.

2) Add or subtract a multiple of a row to another row.

3) Swap two rows.

The end goal of Gauss Jordan Elimination is to convert the system to reduced rowechelon form. The permissible moves are the above three types of reversible operations. The computer program can use to figure out a general procedure that, starting with any system, can identify the appropriate sequence of permissible moves to reach our end goal. The choice of moves will obviously depend on the system we start with. If we want to make the process as algorithmically straightforward as possible, we ultimately do not have to think much about it. The operations that performed are done on the augmented matrix, but they are controlled by the coefficient matrix, in the sense that our decision of what operation to do at each stage is completely governed by the coefficient matrix. It does not ever actually need to look at the right-most column in the decision process for the operation.

\subsection{Matlab}

The computer program that can use to figure out algorithmic of Gauss Jordan Elimination is Matlab. MATLAB or Matrix Laboratory is a tool for numerical computation and visualization. The basic data element of this program is a matrix. It can manipulate arraybased data and it is generally fast to write and run in Matlab program. Since Gauss-Jordan elimination used matrix to solve system of linear equation, so Matlab is suitable to be used. Matlab has several advantages over other methods or language which is its basic data element is the matrix. A simple integer is considered a matrix of one row and one column. Several mathematical operations that work on arrays or matrices are built-in to the Matlab environment. For example, cross-products, dot-products, determinants, inverse matrices.

Actually, Matlab's functionality can be greatly expanded by the addition of toolboxes. Ex: Excel link allows data to be written in a format recognized by Excel, Statistics Toolbox allows more specialized statistical manipulation of data (Anova, Basic Fits, etc). But in this study, the program has not expanded to other toolboxes. Therefore, it is just can be used by opening matlab.

Based on students interviewed after final Engineering Mathematics II test about system of linear equation, many of them said that the way to choose operation which suitable to change augmented matrix into reduced row-echelon form is the most difficult parts. The rest said that the counting operation that involved fraction made it difficult.

Therefore, this study promotes a dynamic syntax of matlab which can show the process of Gauss - Jordan Elimination for the students. In this program, students can input any number element of matrix to the program. They also can choose the form of square matrix. All the consideration led us to the following research question: "How Matlab program could help students to understand Linear Equation System using Gauss-Jordan Method?" 


\section{Research Method}

Computer program Matlab to solve the system of linear equations involving its elementary row operations with the help of Gauss-Jordan elimination has been developed and is given below-

Table 1

The Algorithm of Matlab Program to solve Gauss-Jordan Elimination

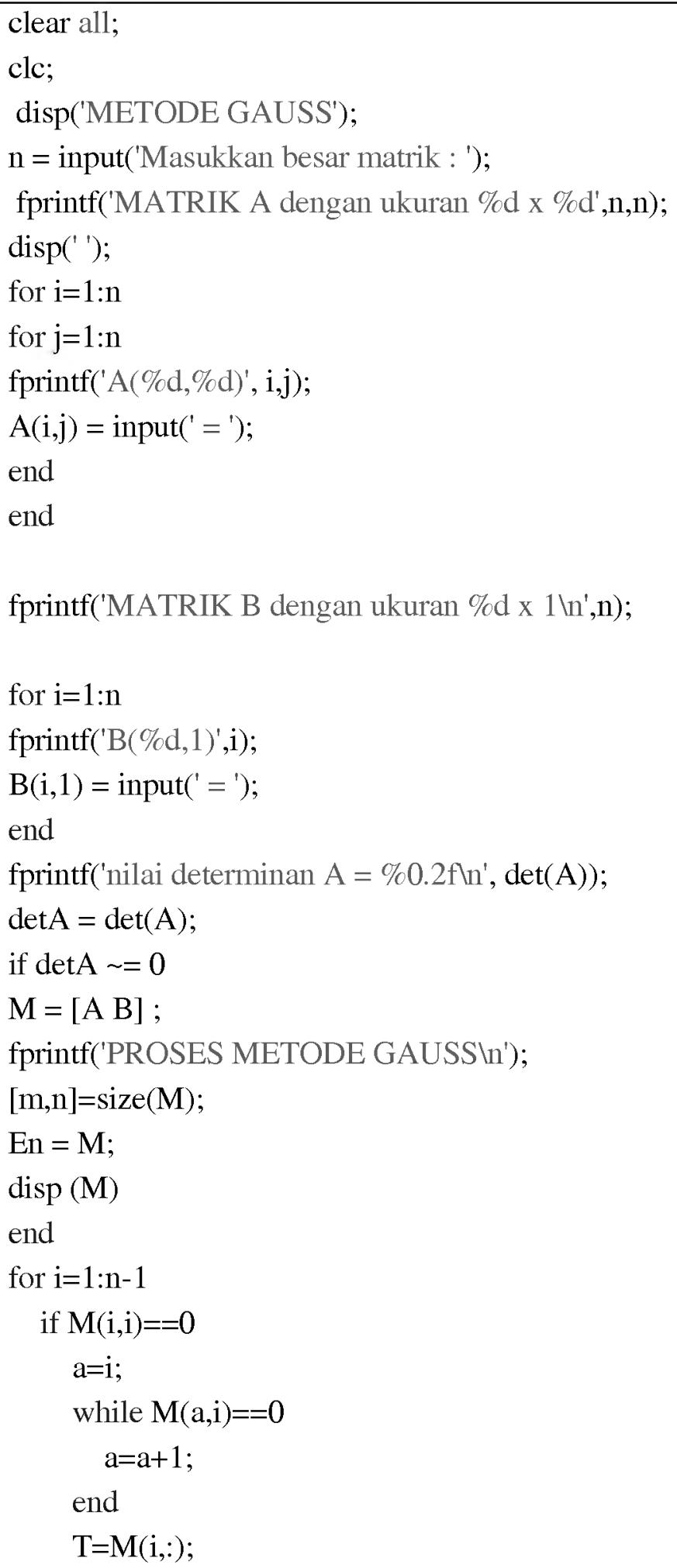




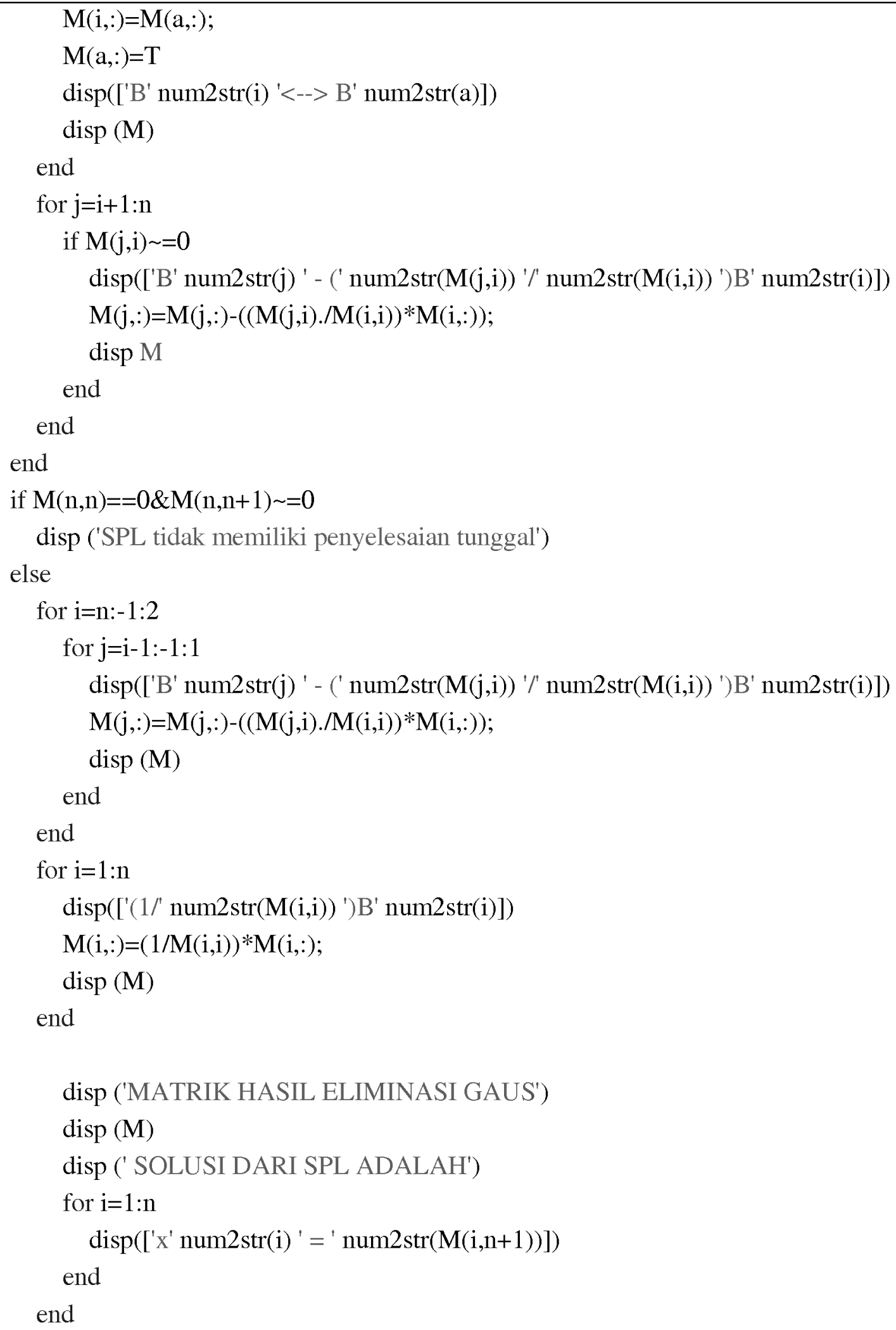

Linear simultaneous equations which can be solved by this program must form square matrix and have determinant. For example these following linear equation system 
Table 2

The System Linear Equation Problems

\begin{tabular}{|c|c|}
\hline Question 1 & Question 2 \\
\hline Solving the Linear Equation System below & Solving the Linear Equation System below \\
$3 y-3 z=0$ & $x+2 y-3 z=0$ \\
$x+4 y+2 z=5$ & $2 x+4 y-2 z=2$ \\
$3 x+6 y+z=7$ & $3 x+6 y-4 z=3$ \\
\hline
\end{tabular}

This program will be showed to the students of Computer Engineering who take Linear Algebra subject of third semester in 2017-2018 which also will learn the Gauss Jordan elimination. This study conducted an interview with 3 of them which represented from the high, middle and low score of their test. The score used is from Matrix test score in the seventh meeting.

The qualitative research technique which used in this study except making computer program is in-depth interviews. In-depth interviews can be defined as conducting intensive individual interviews with a small number of respondents to explore their perspectives on a particular idea, program or situation (Boyce and Neale, 2006). This study used semistructured interviews whereas the interviewer prepares a set of same questions to be answered by all interviewees, however, additional questions might be asked during interviews to clarify and/or further expand certain issues. The interview in this study was conducted after the students of Linear Algebra learn about Gauss Jordan Elimination traditionally and matlab program.

\section{Result}

Linear simultaneous equations given in Table 1 (The System Linear Equation Problems) have been solved with the help of Matlab program and the result is illustrated below

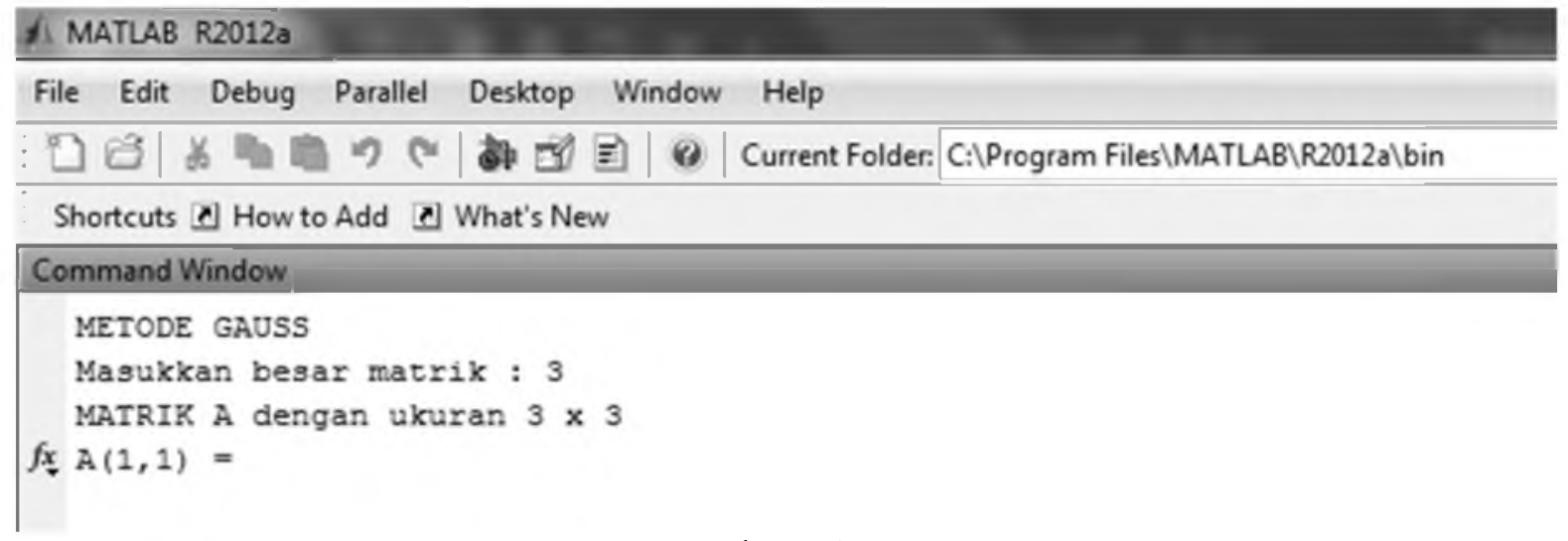

Figure 1

The figure above shows how we can input the form of square matrix in the matlab. It can just be used for $\mathrm{n} \times \mathrm{n}$ matrix. After we input the element of matrix, the program will do elementary row operations to get the reduced-row echelon. It is also showed each elementary row operations that used in the calculation. So, students can learn what kind of elementary row operation used and why it is so. 
Table 3

The answer of System Linear Equation Problems using Matlab Program

\begin{tabular}{|l|l|}
\hline $\begin{array}{l}\text { There is augmented matrix from Linear } \\
\text { simultaneous equations that have determinan }\end{array}$ & $\begin{array}{l}\text { Whereas, for augmented matrix from Linear } \\
\text { simultaneous equations that its determinan }\end{array}$ \\
is 0 MATLA R2012a
\end{tabular}




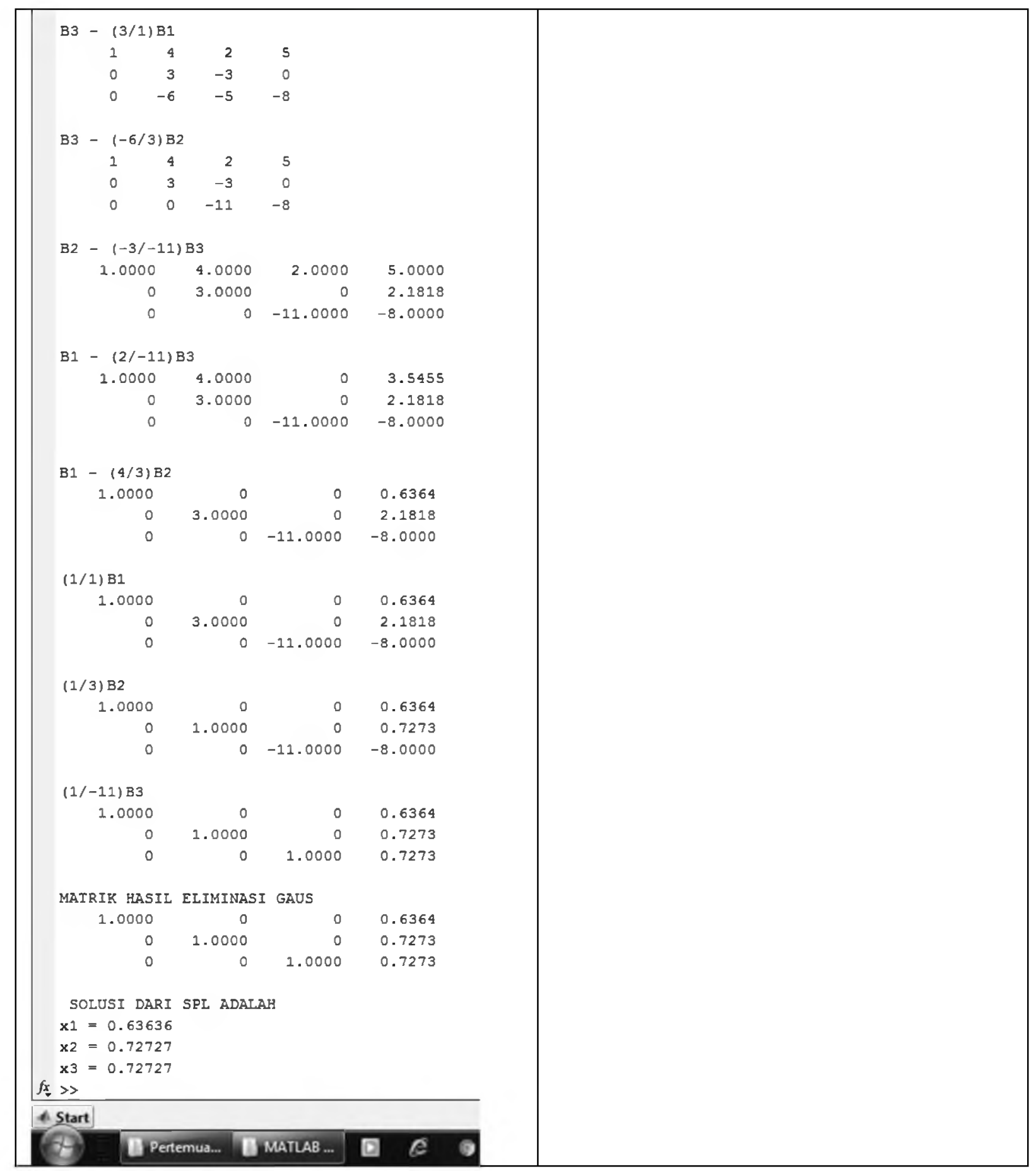

To be used in teaching - learning process, students can be asked to analyze what the change and why it must be changed. Three students were interviewed individually to see what they have understood from the Gauss Jordan elimination using matlab.

Here is the transcript of the high score student about the question number 1 (see table 1.1)

Teacher : Could you see the difference between first and second Matrix?

Student : Yes,

Teacher : What?

Student : The first row is become second row and the second row become the first row.

Teacher : Why it is so? 
Student $\quad$ : To make the element of the first row and first column become 1.

Teacher : How about the second row? Is there something you can conclude about it?

Student : Yeah the first element is 0.

Teacher : So?

Student : So what?

Teacher : Did you notice that when the first element of the second row is 0 , so what ] will you do next?

Student : Uhhmmm yes...that's why the next operation is B3-(3/1)B1.

Teacher : What do you get?

Student $\quad$ : B3-(3/1) B1 means that the third row must be subtracted by three times of first row. This make the column become pivotal 1.

Teacher : Great Job ,..... so can you conclude the reason of the next operation of the Gauss Jordan elimination in this program?

Student : Yeah....I will try.

Teacher : Good....

From the interview with the high score, she can easily catch the reason of the elementary row operation to get the gauss-jordan methods. She thought that it was really helpful to understand the way to do Gauss Jordan method and also to exercise. She think to use this matlab program to check her answer when doing elementary row operation due to she often get stuck when finding what kind of row operation needs to make the matrix become reduced echelon-row.

Meanwhile, the second interviewee, the middle score, gave different finding. He could understand the way and the reason of each step in the Gauss-Jordan methods. But he still does not confident to use his own way to get the elementary row-operation. He tent to use the same way (the same row-operation) when solving new problem, but when it was does not work he need long time to get the right one.

Furthermore, the last interviewee, the low score, said that it was wonderful to have this kind of program. For him, this program has changed their opinion about Gauss-Jordan method. He thought that if the computer could do such thing, he as a human, should be cleverer. But he still had to be guided to know the reason of some row-operation. Also, he still does not confidence to make his own row operation when doing other question. Therefore, he always asked whether his row operation was correct or not. But when he was asked to refer to the previous method that showed in the matlab program, slow but sure he could choose his own row-operation to solve the problem.

To conclude, the matlab program that used in this study was felt helpful by the student as a guidance to solve system of linear equation with Gauss-Jordan method. They said that they can use it as a replacement of teacher at home. But the problem is students have to install Matlab in their computer/laptop.

\section{REFERENCE}

Boyce, C.and Neale, P. (2006) Conducting in-depth Interviews: A Guide for Designing and Conducting In-Depth Interviews.Pathfinder International Tool Series

Smith, L. and Powell, J.(2011) 'An Alternative Method to Gauss-Jordan Elimination: Minimizing Fraction Arithmetic'. The Mathematics Educator, 20(2), pp.44-50. 
Akasekahime (2013)' Gauss-Jordan Reduction Method', DaniWeb. Available at: https://www.daniweb.com/programming/software-development/threads/460534/gaussiordan-reduction-method\#post2002428 [Accessed 8 August 2017]

Chowdhury, N.(2009). 'Gauss Jordan Elimination \& Pivoting'. (c) Technische Universität München 2011. 7 March. Available at:http://m2matlabdb.ma.tum.de/download.jsp?MC ID=3\&MP ID=535 http://m2matlabdb.ma.tum.de/Exr2\&3.m?MP ID=535 [Accessed 8 August 2017] 